\title{
Ectoparasites: immature Japanese hard ticks (Ixodes nipponensis; Acari: Ixodidae) on Korean lizards
}

\author{
Nam-Yong Ra ${ }^{1}$, Jun-Ki Lee ${ }^{2}$, Jung-Hyun Lee ${ }^{1,4}$, Ja-Kyeong Kim ${ }^{1}$, Dae-In Kim ${ }^{1}$, Bin-Na Kim ${ }^{1}$, Il-Hoon Kim ${ }^{1}$ \\ and Daesik Park ${ }^{3, *}$ \\ ${ }^{1}$ Department of Biology, Kangwon National University, Chuncheon 200-701, Korea \\ ${ }^{2}$ Wonju Woman's High School, Wonju 220-945, Korea \\ ${ }^{3}$ Division of Science Education, Kangwon National University, Chuncheon 200-701, Korea \\ ${ }^{4}$ Present address: Division of Nature Conservation Research, National Institute of Environmental Research, Incheon 404-708, \\ Korea
}

\begin{abstract}
Although lizards are important hosts for hard ticks (Ixodidae), very few studies have been conducted in South Korea. To determine whether or not hard ticks can infest lizards endemic to South Korea, we examined 77 lizards of four species (Eremias argus, Sincella vandenburghi, Takydromus amurensis, and Takydromus wolteri) that were collected at 22 different sites between April and October 2010. We confirmed that all four lizard species can be infested by Ixodes nipponensis larvae or nymphs. Of the 62 E. argus examined, we found an average of 12.5 larvae on two lizards and an average of one nymph on one lizard. We found seven nymphs on one S. vandenburghi. We found an average of two nymphs on two of the five T. amurensis and an average of one nymph on four of the nine T. wolteri. Ixodes nipponensis larvae and nymphs were found most frequently on the foreleg axillae (87.8\%), followed by the forelegs $(7.3 \%)$, the eyelids $(2.4 \%)$, and the ears $(2.4 \%)$ of the lizards. To the best of our knowledge, this is the first report of $I$. nipponensis infestations of lizards endemic to South Korea.
\end{abstract}

Key words: classification, ectoparasite, hard tick, Ixodidae, Japanese hard tick, lizard

\section{INTRODUCTION}

Various ectoparasites have been found on reptiles, including ticks, mites, mosquitoes, flies, and leeches (Pough et al. 2004). Because ectoparasites suck lymph and blood from their hosts, they are capable of spreading viruses and bacteria and causing secondary infestations. The typical negative effects of ectoparasites on their hosts include decreased energy, impaired locomotor skills, diminished social activity, reproductive failure, and an elevated risk of mortality for the hosts themselves (Schall and Sarni 1987, Dunlap and Schall 1995, Oppliger et al. 1996, Sorci et al. 1996).
A well-known group of ectoparasites on snakes and lizards are hard ticks (e.g., Ixodidae) (Durden et al. 2002). Larvae and nymphs of the tick species Ixodes have been reported on skinks (Eumeces spp., Scincella spp.), glass lizards (Ophisaurus spp.), spiny lizards (Sceloporus spp.), and grass lizards (Takydromus spp.) (Fujita and Takada 1978, Yoneda 1981, Bauwens et al. 1983, Oliver et al. 1993, Fujita and Takada 1997, Lane and Quistad 1998, Eisen et al. 2004). Prior research has focused on the ectoparasitic patterns of hard ticks on lizards (Bauwens et al. 1983, Oliver et al. 1993), the role of lizards as hosts for hard ticks

\section{Open Access http://dx.doi.org/10.5141/JEFB.2011.033}

This is an Open Access article distributed under the terms of the Creative Commons Attribution Non-Commercial License (http://creativecommons. org/licenses/by-nc/3.0/) which permits unrestricted non-commercial use distribution, and reproduction in any medium, provided the original work is properly cited.
Received 23 June 2011, Accepted 04 July 2011

*Corresponding Author

E-mail: parkda@kangwon.ac.kr

Tel: +82-33-250-6739 
(Matuschka et al. 1991, Eisen et al. 2004), the function of lizards in the spread and life cycle of Lyme disease (Borrelia burgdorferi) (Lane and Quistad 1998, Ostfeld and Keesing 2000, Tijsse-Klasen et al. 2010), and the effects of hard ticks on the behavior and reproduction of lizards (Main and Bull 2000, Fujimoto 2002, Václav et al. 2007).

The life cycle of hard ticks consists of egg, larva, nymph, and adult stages (Sonenshine 1991, Noda et al. 2004, Lee 2009). Hard ticks depend on various terrestrial vertebrates (i.e., rodents, birds, and reptiles) to act as hosts, so that they may feed on their lymph and blood. They also play a key role spreading fungi, viruses, rickettsiae, bacteria, and protozoa among their hosts (Sonenshine 1991). In South Korea, hard ticks infest domestic and wild animals, particularly rodents, birds, skinks (Arthur 1957, Noh 1965, Kim 1970, Kim and Lee 1989, Shim et al. 1992, 1993, 1994, Lee et al. 1997, Eum et al. 2006, Kim et al. 2009), and humans (Kang et al. 1982, Cho et al. 1991, Yoon et al. 1996, Yun et al. 2001). Only a single study has been conducted that relates the Ixodes granulatus ectoparasite to the Korean skink (Scincella vandenburghi) host (Noh 1965).

Consequently, this study determined which types of hard ticks infest which endemic lizards. Additionally, we classified the hard tick species with their associated lizard species.

\section{MATERIALS AND METHODS}

\section{Lizard and tick collection}

To collect ectoparasitic ticks from lizards, we first captured lizard specimens by hand from the following regions: Kyeonggi-do (Kwangju, Yeoju, Yangpyeong, and Icheon), Kangwon-do (Chuncheon, Wonju, Yeongwol, Pyeongchang, and Gangneung), Chungcheong-do (Jecheon, Chungju, Danyang, Taean, Boryeong, and Seocheon), and Kyeongsang-do (Cheongsong, Gunwei, Sungju, Kimcheon, Gumi, Goryeong, and Hapcheon). This specimen collection period lasted from April to October 2010. Upon catching a lizard, we determined its species and examined it for the presence of hard ticks. In the event that we found ectoparasitic ticks on a lizard's body, we recorded their number and the locations where they were attached. Next, we measured the lizard's snout-vent length (in increments of $0.1 \mathrm{~cm}$ ) and its body weight (in increments of $0.1 \mathrm{~g}$ ) using a digital vernier caliper (CD-15CPX; Mitutoyo, Kawasaki, Japan) and a digital balance (TMB 120-1; Kern, Balingen, Germany), respectively. Finally, we released the lizards at the site where they were caught. Additionally, we also obtained a sample of Korean skinks (S. vandenburghi) infested by ticks that were caught in Sinan, Jeonnam in April 2009 by a researcher at Jeju National University.

\section{Observation and classification of ticks}

Before conducting tick observations, we cleaned the ticks by submerging them in a $10 \% \mathrm{KOH}$ solution for 1-3 hours. Afterwards, we observed the ticks with either one or both of the following light microscopes: a dissecting microscope (\#5424 Stereo Crystal-Pro; Konus, Verona, Italy), or an Eclipse 50i (Nikon, Tokyo, Japan). To investigate the level of detail necessary to construct a classification key for the ticks, we used a scanning electron microscope (SEM). Before this set of observations, the ticks were treated following the method of Park et al. (2008). The ticks were fixed using a $4 \%$ glutaraldehyde solution (in $0.2 \mathrm{M}$ phosphate buffer, $\mathrm{pH}$ 7.4), washed three times using the same buffer, then serially dehydrated in $50,60,70,80,90$, and $100 \%$ ethanol for $30 \mathrm{~min}$ at each concentration. Next, the medium was exchanged three times (for $30 \mathrm{~min}$ each time) with isoamyl acetate. The ticks were dried using critical-point drying, mounted on a specimen stub, coated with Au-Pd (E-1010; Hitachi, Tokyo, Japan), and observed under a S-3500N low-vacuum SEM (Hitachi) at the Korea Basic Science Institute, Chuncheon, Kangwon. By employing the SEM in our observations, we observed a total of 12 larvae on the Mongolian racerunner (Eremias argus) and a combined total of four nymphs on the Korean skink (S. vandenburghi) and the white-striped grass lizard (Takydromus wolteri). To locate classification keys for the Ixodes ticks, we employed Yamaguti et al. (1971) and Lee (2009). To help determine the species of larval and nymphal ticks found, classification keys by Ono (1962), Kitaoka and Saito (1967), and Yamaguti et al. (1971) were also used.

\section{RESULTS}

We collected 77 lizards representing four species $(E$. argus, S. vandenburghi, Takydromus amurensis, and T. wolteri) from 22 sites. Of the 77 lizards collected, 10 lizards from Chuncheon, Yeongwol, Taean, and Sinan were infested by a combined total of 41 hard ticks (Table 1). These ticks were found mainly on the foreleg axillae $(87.8 \%)$, followed by the forelegs $(7.3 \%)$, the eyelids (2.4\%), and the ears (2.4\%) (Fig. 1). 

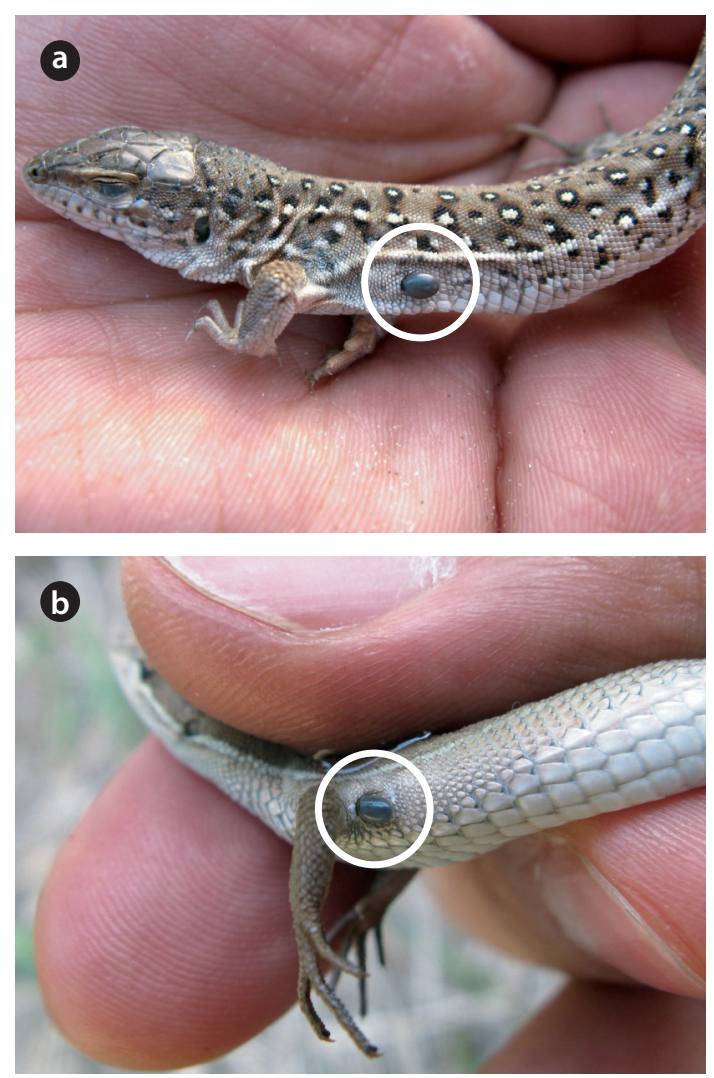

Fig. 1. Ixodes nipponensis nymphs on (a) the Mongolian racerunner (Eremias argus) and (b) the white-striped grass lizard (Takydromus wolteri).

Because the hard ticks had a serrated hypostome on the capitulum at the anterior end of the body, as well as a scutum and an anal groove that rounded the anus anteriorly and was without a festoon, we classified these hard ticks as Ixodes ticks (Fig. 2). Of the 41 ticks, 16 were nymphs with four pairs of legs but no genital aperture, whereas 25 ticks were larvae and had three pairs of legs. In both larvae and nymphs, the cornua and auricula protruded in a triangular shape from the left and right bottom end of the capitulum and were visible in both dorsal and ventral views, respectively (Figs. 3a, 3b, 4a, and 4b).
The end of the larvae hypostome was blunt, whereas that of nymphs was sharp. On the hypostome, both larvae and nymphs had 3/3 upper tooth rows and 2/2 lower tooth rows (Figs. 3c and 4c). Both larvae and nymphs had relatively long external and internal spurs on the first coxal plate, whereas the external spurs on the remaining coxae were not extended to the next coxal plate (Figs. 3d and $4 \mathrm{~d})$. The postscutal setae were forked, and the forked setae were often observed on other parts of the body such as legs (Figs. 3e, 3f, 4e, and 4f). Based on these classification characteristics, the hard ticks collected were all identified as Ixodes nipponensis larvae or nymphs.

The 16 ticks collected from Chuncheon, Yeongwol, and Sinan between April and May were all nymphs, whereas the 25 ticks collected in July from E. argus were all larvae. Of the 62 E. argus collected, we found an average of 12.5 larvae on two lizards and an average of one nymph on one lizard. Additionally, we found seven nymphs on one $S$. vandenburghi, an average of two nymphs on two of five T. amurensis, and an average of one nymph on four of nine T. wolteri examined (Table 1).

\section{DISCUSSION}

This study identified Japanese hard tick (i.e., I. nipponensis) larvae and nymphs on the bodies of four lizard species endemic to South Korea (E. argus, S. vandenburghi, T. amurensis, and T. wolteri). To our knowledge, this is the first report of I. nipponensis infestation of lizards endemic to South Korea.

The infestation rates by larval and nymphal I. nipponensis depended on the species of lizard infested. In general, Ixodes tick (Bauwens et al. 1983) infestation rate is affected by body size, home range size, activity periods, and use of different habitats. Previous studies have shown that skinks and grass lizards, which live mainly on the ground in grasslands and on the floors of forests, respectively, have more ticks on their bodies than those of anole lizards, which live mainly in the upper stories

Table 1. Japanese hard tick (Ixodes nipponensis) larvae and nymphs found on lizard species endemic to South Korea

\begin{tabular}{lccc}
\hline Lizard species & No. of lizards examined & $\begin{array}{c}\text { Lizards infested by larva } \\
\text { (No. of larvae found) }\end{array}$ & $\begin{array}{c}\text { Lizards infested by nymphs } \\
\text { (No. of nymphs found) }\end{array}$ \\
\hline Sincella vandenburghi & 1 & 0 & $1(7)$ \\
Takydromus amurensis & 5 & 0 & $2(4)$ \\
Takydromus wolteri & 9 & 0 & $4(4)$ \\
Eremias argus & 62 & $2(25)$ & $1(1)$ \\
\hline
\end{tabular}



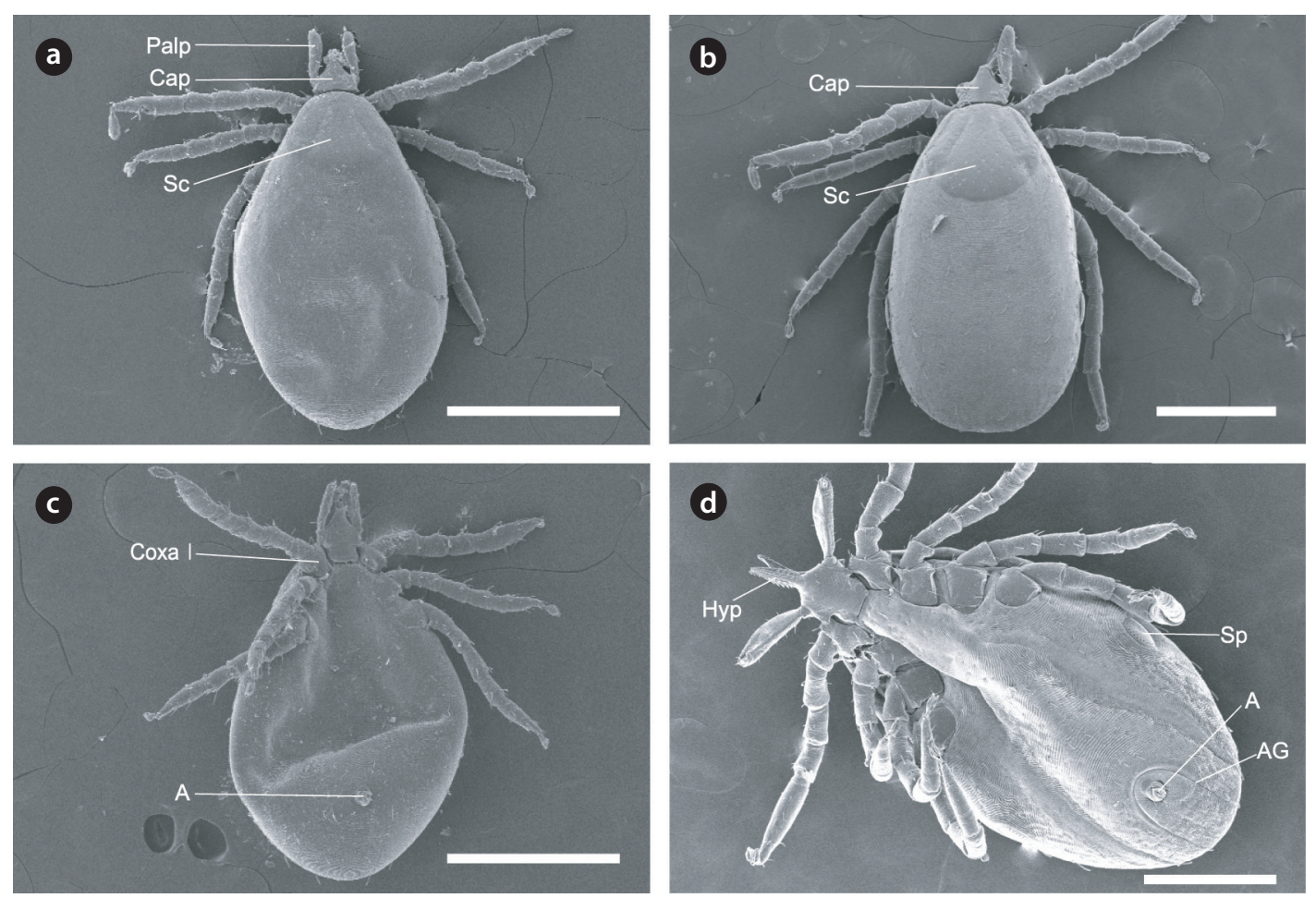

Fig. 2. Dorsal and ventral views of a typical larva $(a, c)$ and nymph $(b, d)$ of Ixodes nipponensis collected from the Mongolian racerunner (Eremias argus) and the white-striped grass lizard (Takydromus wolteri), respectively. A, anus; AG, anal groove; Cap, capitulum; Hyp, hypostome; Sc, scutum; Sp, spiracle. Scale bars $=0.5 \mathrm{~mm}$.

of plants (Apperson et al. 1993, Durden et al. 2002). Such studies have also indicated that there is a higher chance of infestation by hard ticks when potential hosts are on the ground. Unfortunately, the sample size of each lizard species examined in this study varied widely; consequently, additional studies with larger, more comparable lizard samples will be necessary to compare the Ixodes tick infestation rate in different lizard species.

Consistent with previous findings, most of the ticks found in this study were located on the lizards' foreleg axillae. Hard ticks are known to be found principally on areas where the skin is weak and well-lined, although they can also be occasionally collected from other parts of the body (Durden et al. 2002). Among the skinks (genus Eumeces), Ixodes ticks were frequently attached near the shoulders, legs, and armpits, whereas they were attached mostly at the lateral grooves on the glass lizard (genus Ophisaurus) (Apperson et al. 1993, Oliver et al. 1993). Moreover, the lizards' armpits, which are particularly difficult to reach and are well protected from the outside, are also recognized as the most susceptible place for Ixodes tick infestation (Bauwens et al. 1983, Oliver et al. 1993).

The larval and nymphal Ixodes ticks collected in this study displayed several distinctive classification characteristics matching those of I. nipponensis. First, the scutal setae were distinctively shorter than the dorsal setae. Second, the external spurs on the coxae (except the first coxa) were not extended to the next coxa plate. Third, the end of the larvae's hypostome was blunt, whereas that of nymphs was sharp. Fourth, the postscutal setae were forked. Fifth, forked setae were often observed on other parts of the body such as legs. Based on these previously described characteristics (Ono 1962, Kitaoka and Saito 1967, Yamaguti et al. 1971), we identified the hard ticks collected as larval or nymphal Japanese hard ticks (I. nipponensis).

Although immature larval and nymphal Ixodes ticks use both small mammals and other reptiles as hosts, Ixodes ticks such as I. ricinus (Matuschka et al. 1991), I. scapularis (Apperson et al. 1993), and I. pacificus (Eisen et al. 2004) are known to prefer lizards as hosts. In South Korea, small mammals, including the black-striped field mouse (Apodemus agrarius) and the Ussuri white-toothed shrew (Crocidura lasiura), are frequently infested with Ixodes ticks (Shim et al. 1992, 1993, Kim et al. 2009). However, our research is the first to show that lizards endemic to South Korea are an important host for immature Ixodes 

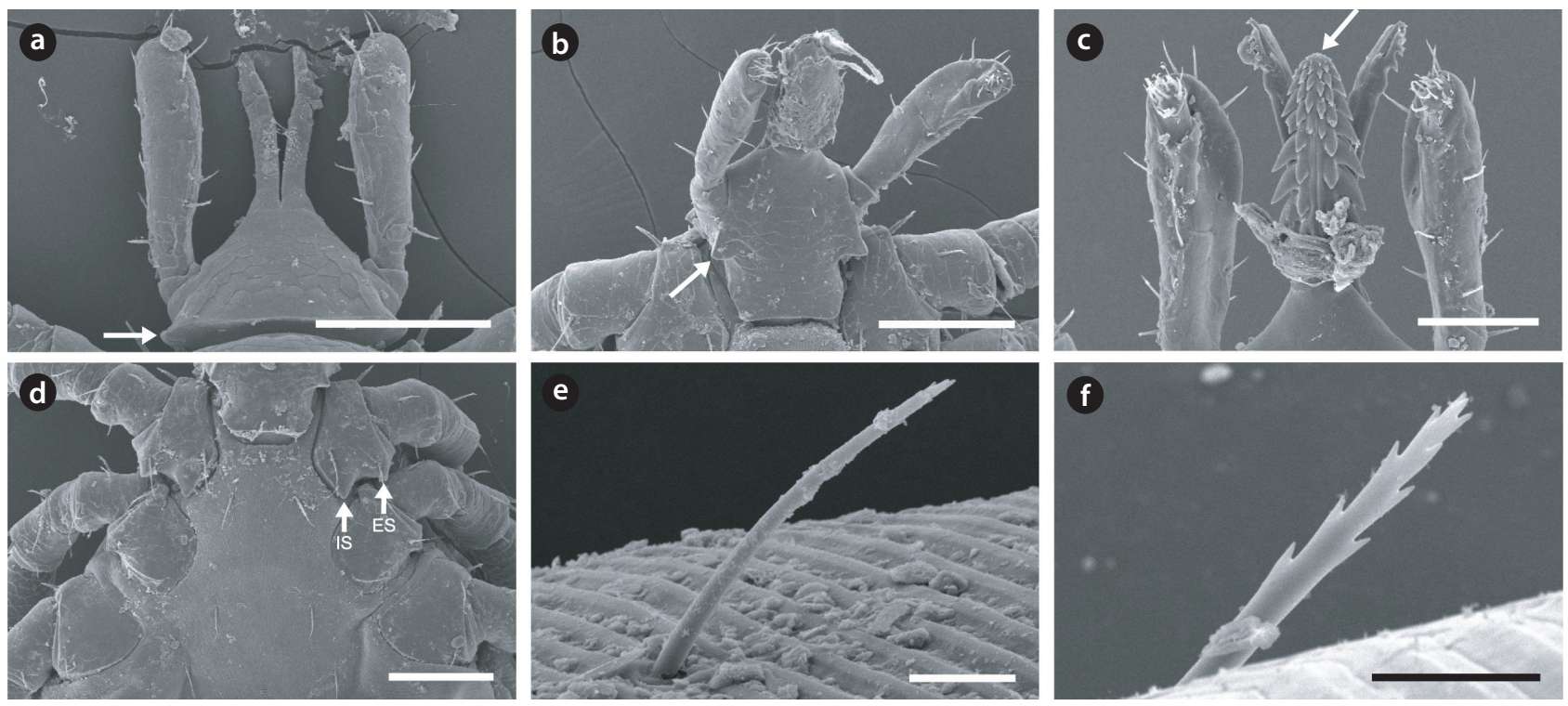

Fig. 3. Classification keys for larval Ixodes nipponensis are indicated by the following arrows: (a) cornua on the dorsal capitulum, (b) auricula on the ventral capitulum, (c) hypostome, (d) external spur (ES) and internal spur (IS) on the coxa I, (e) postscutal seta, and (f) the tip of the postscutal seta. Scale bars $=100$ $\mu \mathrm{m}(\mathrm{a}, \mathrm{b}, \mathrm{d}), 50 \mu \mathrm{m}(\mathrm{c}), 10 \mu \mathrm{m}(\mathrm{e}, \mathrm{f})$.
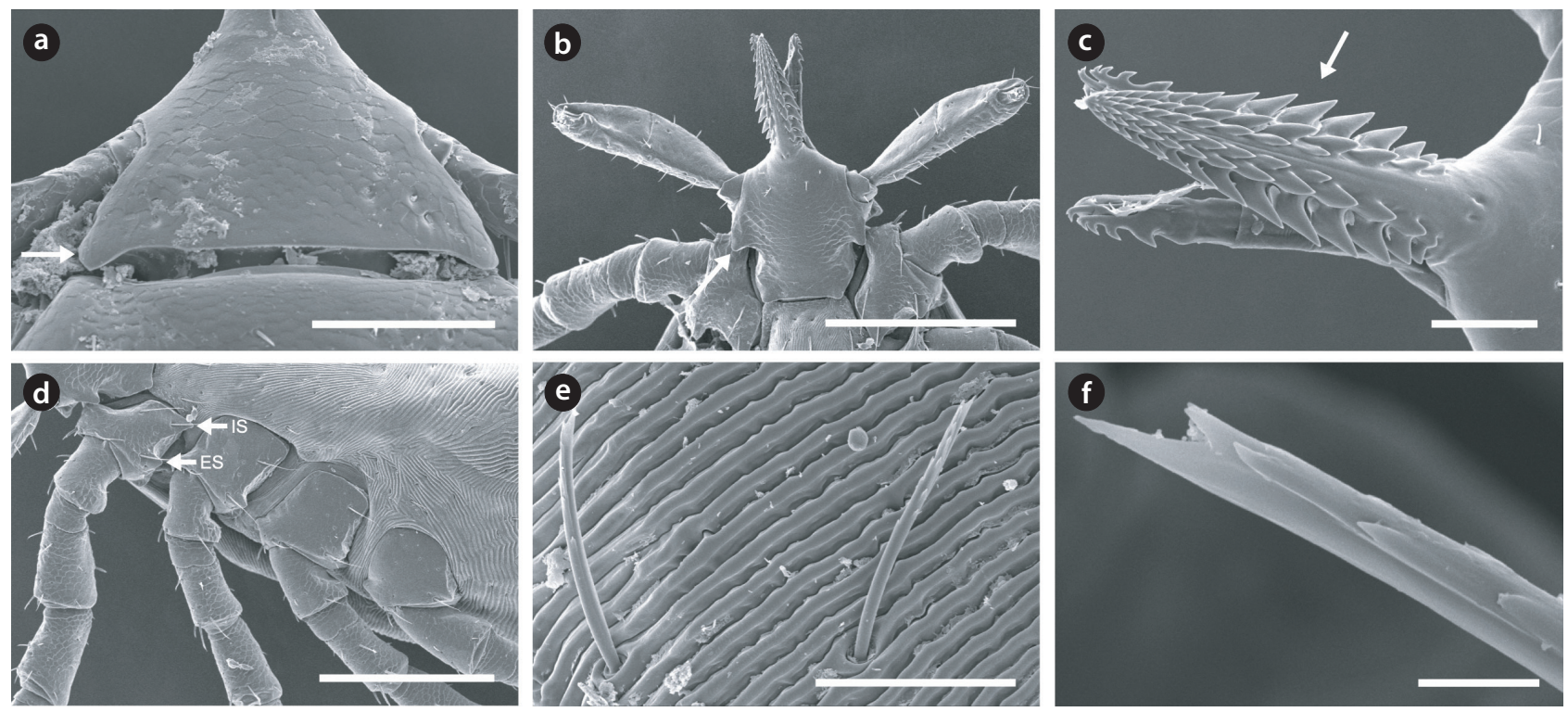

Fig. 4. Classification keys for nymphal Ixodes nipponensis are indicated by the following arrows: (a) cornua on the dorsal capitulum, (b) auricula on the ventral capitulum, (c) hypostome, (d) external spur (ES) and internal spur (IS) on the coxa I (e) postscutal seta, and (f) the tip of the postscutal seta. Scale bars $=100 \mu \mathrm{m}(\mathrm{a}), 300 \mu \mathrm{m}(\mathrm{b}, \mathrm{d}), 50 \mu \mathrm{m}(\mathrm{c}, \mathrm{e}), 5 \mu \mathrm{m}(\mathrm{f})$.

ticks. As ectoparasites, ticks negatively affect a host's health and reproduction (Sonenshine 1991, Main and Bull 2000). It seems reasonable to assume that Korean lizards would be negatively impacted by ticks in the field as well. Finally, it is important to pay close attention to such ectoparasites on lizards in captivity, for purposes related to keeping of pets and to conservation.

\section{ACKNOWLEDGMENTS}

We thank Dr. M. H. Jang for allowing us to use the Korean skink sample and to Dr. W. K. Lee for his valuable tick identification comments. This study was supported by the Korean Ministry of Environment as "The Ecotechnopia 21 project (\#052-091-080)." 


\section{LITERATURE CITED}

Apperson CS, Levine JF, Evans TL, Braswell A, Heller J. 1993. Relative utilization of reptiles and rodents as hosts by immature Ixodes scapularis (Acari: Ixodidae) in the coastal plain of North Carolina, USA. Exp Appl Acarol 17: 719-731.

Arthur DR. 1957. Studies on exotic Ixodes ticks (Ixodoidea, Ixodidae) from United States navy and army activities. J Parasitol 43: 681-694.

Bauwens D, Strijbosch H, Stumpel AHP. 1983. The lizards Lacerta agilis and L. vivipara as hosts to larvae and nymphs of the tick Ixodes ricinus. Holarct Ecol 6: 32-40.

Cho NJ, Bang DS, Cho BK, Oh YJ, Lee WK. 1991. Two cases of tick bites caused by Ixodes nipponesis. Korean J Dermatol 29: 533-537.

Dunlap KD, Schall JJ. 1995. Hormonal alterations and reproductive inhibition in male fence lizards (Sceloporus occidentalis) infected with the malarial parasite Plasmodium mexicanum. Physiol Zool 68: 608-621.

Durden LA, Olliver JH Jr, Banks CW, Vogel GN. 2002. Parasitism of lizards by immature stages of the blacklegged tick, Ixodes scapularis (Acari, Ixodidae). Exp Appl Acarol 26: 257-266.

Eisen L, Eisen RJ, Lane RS. 2004. The roles of birds, lizards, and rodents as hosts for the western black-legged tick Ixodes pacificus. J Vector Ecol 29: 295-308.

Eum SS, Koh WS, Hur CH, Bae JJ. 2006. A survey for tickborne disease agents from farm deer in the eastern area of Jeonbuk. Korean J Vet Serv 29: 103-110.

Fujimoto K. 2002. Effect of the prolonged time after molting on the induction of the behavioral diapause of Ixodes nipponensis nymphs (Acari: Ixodidae) by exposure to a short-day photoperiod. J Acarol Soc Jpn 11:101-103.

Fujita H, Takada N. 1978. Studies on Ixodid fauna in the northern part of Honshu, Japan: 3. Preliminary notes on Ixodes nipponensis (Ixodoidea; Ixodidae) found on the small reptile, Takydromus tachydromoides. Med Entomol Zool 29: 269-271.

Fujita H, Takada N. 1997. Collection records of immature Ixodes nipponensis and Ixodes persulcatus ticks found on the small reptile, Takydromus tachydromoides in the northeastern part of Honshu, Japan. Med Entomol Zool 48: 123-125.

Kang WH, Chang KH, Chun SI, Koh CJ, Cho BK. 1982. A case of tick bite caused by Ixodes species. Korean J Dermatol 20: 789-793.

Kim HC, Kim JH, Jo YS, Chong ST, Sames WJ, Klein TA, Robbins RG. 2009. Records of Ixodes pomeranzevi Serdyukova, 1941 (Acari: Ixodidae) from small mammals in northern Gyeonggi and Gangwon Provinces, Republic of Korea. Syst Appl Acarol 14: 129-135.

Kim MH, Lee HP. 1989. The community structure and dynamic of parasitic mites on house rats. Korean J Ecol 12: 123-132.

Kim SH. 1970. Study on the ticks of Chejudo-life cycle. Korean J Parasitol 8: 51-57.

Kitaoka S, Saito Y. 1967. Ixodes nipponensis n. sp. (Ixodoidea, Ixodidae), a common cattle tick in Japan. Natl Inst Anim Health Q (Tokyo) 7: 74-83.

Lane RS, Quistad GB. 1998. Borreliacidal factor in the blood of the western fence lizard (Sceloporus occidentalis). J Parasitol 84: 29-34.

Lee WK. 2009. Illustrated Encyclopedia of Fauna \& Flora of Korea: Vol. 44 (Acari: Anactinotrichida). Ministry of Education, Science and Technology, Seoul.

Lee WK, Lim JW, Lee SY, Lee IY. 1997. Redescription of Haemaphysalis flava and Ixodes tanuki collected from a raccoon dog in Korea. Korean J Parasitol 35: 1-8.

Main AR, Bull CM. 2000. The impact of tick parasites on the behaviour of the lizard Tiliqua rugosa. Oecologia 122: 574-581.

Matuschka FR, Fischer P, Musgrave K, Richter D, Spielman A. 1991. Hosts on which nymphal Ixodes ricinus most abundantly feed. Am J Trop Med Hyg 44: 100-107.

Noda S, Yamamoto S, Fujita H. 2004. Seasonal occurrence of Ixodid ticks in the northwestern part of Kagoshima prefecture, Japan. J Acarol Soc Jpn 13: 83-86.

Noh YT. 1965. A taxonomical study on ticks in Korea (I): the genus Ixodes. Korean J Zool 8: 73-76.

Oliver JH Jr, Cummins GA, Joiner MS. 1993. Immature Ixodes scapularis (Acari: Ixodidae) parasitizing lizards from the southeastern U.S.A. J Parasitol 79: 684-689.

Ono Z. 1962. Descriptions on the immature forms of Ixodes sp., reared in the laboratory of Ohara General Hospital, Fukushima, Japan. Annu Rep Ohara Gen Hosp 6: 24-29.

Oppliger A, Célérier ML, Clobert J. 1996. Physiological and behavior changes in common lizards parasitized by haemogregarines. Parasitology 113: 433-438.

Ostfeld RS, Keesing F. 2000. Biodiversity and disease risk: the case of Lyme disease. Conserv Biol 14: 722-728.

Park D, Lee JH, Ra NY, Eom J. 2008. Male salamanders Hynobius leechii respond to water vibrations via the mechanosensory lateral line system. J Herpetol 42: 615-625.

Pough FH, Andrews RM, Cadle JE, Crump ML, Savitzky AH, Wells KD. 2004. Herpetology. $3^{\text {rd }}$ ed. Pearson Prentice Hall, Upper Saddle River, NJ.

Schall JJ, Sarni GA. 1987. Malarial parasitism and the behavior of the lizard, Sceloporus occidentalis. Copeia 1987: 84-93. 
Shim JC, Yoon YH, Cho YB, Lee JY, Shin EH, Yang YC, Park JE, Lee WG, Yu HS, Park KH. 1994. Studies on the potential vector of ticks (Ixodidae) in transmitting of Lyme disease (Borrelia burgdorferi) (III). Rep Natl Inst Health 31: 149-155.

Shim JC, Yoon YH, Kim CL, Cho YB, Lee JY, Shin EH, Yang YC, Baik MK, Yu WH, Yu HS, Park KH and Kim KH. 1993. Studies on the vector potential of ticks (Ixodidae) in transmitting of Lyme disease (Borrelia burgdorferi) (II): vector incrimination and seasonal occurrence of Ixodes granulatus. Rep Natl Inst Health 30: 131-136.

Shim JC, Yoon YH, Kim CL, Shin EH, Yang YC, Cho YB, Lee JY. 1992. Studies on the vector of Lyme disease (Borrelia burgdorferi) (I): geographical distribution and seasonal prevalence. Rep Natl Inst Health 29: 123-130.

Sonenshine DE. 1991. Biology of Ticks. Vol. 1. Oxford University Press, Madison Avenue, New York.

Sorci G, Clobert J, Michalakis Y. 1996. Costs of reproduction and cost of parasitism in the common lizard, Lacerta vivipara. Oikos 76: 121-130.
Tijsse-Klasen E, Fonville M, Reimerink JHJ, van der Sluijs AS, Sprong H. 2010. Role of sand lizards in the ecology of Lyme and other tick-borne diseases in the Netherlands. Parasite Vector 3: 42-53.

Václav R, Prokop P, Fekiač V. 2007. Expression of breeding coloration in European green lizards (Lacerta viridis): variation with morphology and tick infestation. Can J Zool 85: 1199-1206.

Yamaguti N, Tipton VJ, Keegan HL, Toshioka S. 1971. Ticks of Japan, Korea, and the Ryukyu Islands. Brigham Young Univ Sci Bull Biol Ser 15: 1-226.

Yoneda Y. 1981. Additional report of Ixodes nipponensis found on the small reptile, Takydromus tachydromoides, in Kyushu. Med Entomol Zool 32: 82-83.

Yoon SY, Kim KH, Suhr KB, Cho BK, Nam IH, Lee WK, Lee JH, Park JK. 1996. A case of tick bite caused by Haemaphysalis flava. Korean J Dermatol 34: 326-330.

Yun SK, Ko GB, Chon TH. 2001. Tick bite: report of a case and review of Korean cases. Korean J Dermatol 39: 891-895. 